\title{
Factors for Determining Preferred Levels of Portable Listening Device
}

\author{
Wondo $\mathrm{Na}^{1}$, Sunghwa You', Woojae $\mathrm{Han}^{2}$ \\ 'Department of Speech Pathology and Audiology, Graduate School, Hallym University, Chuncheon, Korea \\ ${ }^{2}$ Division of Speech Pathology and Audiology, Research Institute of Audiology and Speech Pathology, College of Natural Sciences, Hallym University, \\ Chuncheon, Korea
}

\section{휴대용 음향기기의 선호청취음량을 결정하는 요인들}

나원도 ${ }^{1} \cdot$ 유성화 ${ }^{1}$ 한우재 ${ }^{2}$

한림대학교 일반대학원 언어병리청각학과', 한림대학교 자연과학대학 언어청각학부 · 청각언어연구소 ${ }^{2}$

\begin{abstract}
Purpose: With increasing on concern of recreational noise-induced hearing loss in young population, the present study aimed to investigate factors for determining preferred listening levels of the portable listening device users. Methods: For measuring the preferred listening levels of forty young listeners with normal hearing, four types of earphone having different insertion depths to the ear canal was applied under three levels of background noise (quiet, $40 \mathrm{dBA}$ and $70 \mathrm{dBA}$ ) while listening to four music genres as exogenous factors. Also, their acceptable noise levels (ANLs) were identified as an endogenous factor. Results: As we expected, the preferred listening levels were significantly increased as the background noise level (BNL) increased. Among the music genres, classic and ballad (or R\&B) were the lowest and highest listening levels, respectively. In addition, when the insertion depth to the ear canal was longer, the listening levels were decreased regardless of music genres and BNLs, except for the headphone that totally covered user's pinna. Interestingly, there was a partially correlation between the preferred listening levels in the experimental conditions and the ANLs. Conclusion: The present results imply that both exogenous and endogenous factors might affect user's preferred listening levels of the portable listening device although a further study to see any interaction among the factors should be followed.
\end{abstract}

Key Words: Preferred listening levels, Earphone type, Insertion depth of earphone, Music genre, Acceptable noise level.

Received: October 3, 2018 / Revised: October 11, 2018 / Accepted: October 15, 2018

Correspondence: Woojae Han, Division of Speech Pathology and Audiology, College of Natural Sciences, Hallym University, 1 Hallymdaehak-gil, Chuncheon 24252, Korea

Tel: +82-33-248-2216 / Fax: +82-33-256-3420 / E-mail: woojaehan@hallym.ac.kr

\section{INTRODUCTION}

소음성 난청(noise-induced hearing loss, NIHL)은 노인성 난청 다음으로 가장 흔한 후천적 난청으로, 과도한 소음 노출로 인해 발생되는 청력 손실이다. Sliwinska-Kowalska \& Davis (2012)의 조사에 따르면, 전 세계 인구 중 약 5억 명이 소음성 난 청의 발병 위험군에 있는 것으로 추정된다. 과거 소음성 난청은 기계공, 판금공, 군인 등 직업 특성상 하루 8 시간 이상 $85 \mathrm{dBA}$ 의 고강도 소음 환경에 노출되는 일부 근로자들에게만 국한되

(c) This is an Open Access article distributed under the terms of the Creative Commons Attribution Non-Commercial License (https://creativecommons.org/licenses/by-nc/4.0) which permits unrestricted non-commercial use, distribution, and reproduction in any medium, provided the original work is properly cited.
었던 직업적 난청이었다. 그러나 현대 사회에서는 삶의 질의 증 가로 인해 콘서트 및 스포츠 경기의 관람, 이어폰을 통한 휴대 폰 음향기기를 사용한 음악 청취 등 취미 및 여가활동의 시간 이 증가되면서 고강도 소음에의 지속적인 노출로 인한 유희적 소음성 난청(recreational NIHL)에 대한 주의가 대두되고 있 다(Vogel et al., 2012). 최근에는 CD plyer, PMP, MP3 player 의 기능이 스마트폰 기기 내 하나의 기능으로 내장되면서, 휴대 용 음향기기의 사용자는 젊은 청소년층을 포함하여 전 세대로 급속히 증가되고 있다(Yu et al., 2016). 2011년도에 판매된 스마 트폰은 전 세계적으로 약 4억 7,000만 개로 추정되며 이 수치는 꾸준히 상승할 전망이다(Minges, 2012). 따라서 이러한 추세에 맞춰 미국과 유럽을 중심으로 젊은 층의 휴대용 음향기기 사용 
으로 인한 청력 손실에 관한 연구가 활발히 진행되고 있다(Lee et al., 2013).

휴대용 음향기기의 선호청취음량에 영향을 미치는 요인들은 다양하지만, 그중 가장 대표적인 것이 1) 청취하는 환경의 배경 소음 정도, 2) 청취 음악의 장르, 3) 착용하는 이어폰의 종류 등 이 있다. 가장 대표적인 선행연구로서, Kim et al.(2011)은 25명 의 건청 성인을 대상으로 이어폰의 유형과 소음 환경 조건이 선호청취음량에 미치는 영향에 대해 확인하였다. 이어버드, 이 어커널, 이어클립의 3 가지 이어폰 종류를 사용하였고, 조용한 상황, $70 \mathrm{dBA}$ 의 찻길 소음, $70 \mathrm{dBA}$ 의 대화 소음의 3 가지 배경 소음을 적용하여 노래 한 곡의 후렴 부분이 반복되는 지점에서 선호청취음량을 실이측정을 통하여 계산하였다. 조용한 상황에 서 이어커널은 60.3 sound pressure level in decibel (dB SPL), 이어버드는 $64.1 \mathrm{~dB} \mathrm{SPL}$, 이어클립은 $67.3 \mathrm{~dB} \mathrm{SPL}$ 로 고막과의 거리가 가까워질수록 작은 선호청취음량을 보였으며, $70 \mathrm{dBA}$ 의 찻길소음과 대화소음에서도 동일한 패턴을 보였다. 또한 배 경소음이 커지면서 선호청취음량도 함께 증가하는 패턴을 보였 다. 반면, Hodgetts et al.(2007)의 연구에서는 38명의 건청 성인 을 대상으로 3 가지의 이어폰 종류(이어버드, 헤드폰, 소음감쇄 효과가 있는 헤드폰)와 3 가지의 배경소음 상황(조용한 상황, 70 $\mathrm{dBA}$ 의 거리소음과 다화자잡음)에서 한 곡의 노래 후렴 부분이 반복되는 지점에서 선호청취음량을 실이측정을 통하여 분석하 였다. 조용한 상황에서 이어버드는 $77.8 \mathrm{~dB}$, 헤드폰은 $75.2 \mathrm{~dB}$, 소음감쇄 헤드폰은 $75.2 \mathrm{~dB}$ 로 측정되었다. 배경소음이 높아질 수록 선호청취음량이 커지는 패턴을 나타냈으며, 소음감쇄 기 능이 추가된 헤드폰은 조용한 상황과 배경소음 상황 모두에서 가장 작은 선호청취음량을 나타냈다. 즉, Kim et al.(2011)의 연 구와는 다르게 Hodgetts et al.(2007) 연구에서는 고막과의 거 리가 멀어졌지만 오히려 선호청취음량이 더 작게 측정되어 이 개 전체를 감싸는 헤드폰의 사용으로 외이도 내의 음압을 상승 시켰다고 생각된다. 그러나 이러한 연구들은 배경소음의 정도 에 따라 1 2개의 다른 헤드폰의 종류를 적용하며 선호청취음 량에 대하여 단편적인 비교만 있을 뿐 체계적인 실험을 통한 종합적인 결과를 보여주지는 못하였다.

더불어, 선호청취음량은 개인 선호에 따라 다르다. 큰 음량을 선호하는 사람과 조용하게 음악을 청취하기를 원하는 사람들 이 있다. 즉, 개인의 선호청취음량은 이어폰 종류 및 이어폰의 외이도 내 삽입 정도와 같은 외부적인 요소뿐 아니라, 개인적 청취 쾌적 수준이나 청취 습관 등 내부적인 요소에도 좌우된다 (Kumar et al., 2009). 그럼에도 아직까지 국내외 연구들에서는 선호청취음량에 영향을 미치는 내부적인 요인들을 확인한 것이 부재하다. 이러한 내부적인 요인으로 Nabelek et al.(2004)은 청 취자의 행동을 분석하기 위해 청취자의 행동을 이해하는 데 폭
넓게 적용되는 소음의 수용을 고려하는 것이 바람직하다고 제안 하였다. 그중 특히 수용소음레벨(acceptable noise level, ANL) 은 배경소음의 상황 차이로 인한 청취자 개개인의 차이를 이해 하는 데 유용할 수 있고, 개개인에 영향을 줄 수 있는 상황의 변 화를 설명하는 데 유용할 수 있다(Franklin et al., 2006). 이에 본 연구에서는 휴대용 음향기기의 선호청취음량에 영향을 미 치는 요인들 중 배경소음, 음악 장르, 이어폰 삽입 정도의 외적 요인들과 수용소음레벨의 내적 요인과의 상관성을 확인하여 보다 심도 있게 휴대용 음향기기 사용자들의 음량 변화에 기여 하는 영향을 조사하고자 한다.

\section{MATERIALS AND METHODS}

\section{연구 대상}

정상 청력을 가진 20대 성인 40명(남녀 각각 20명; 평균 연령: 23.1세, 표준편차: \pm 2.37)을 대상으로 배경소음 수준에 따른 음향기기의 선호청취음량을 측정하였다. 연구 대상자는 과거 이과적 병력이 없고, 고막운동성검사에서는 $\mathrm{A}$ 유형을 나타냈다. 또한 $0.5,1,2 \mathrm{kHz}$ 의 3 분법 순음평균역치는 우측 $6.8 \mathrm{~dB} \mathrm{HL}$, 좌측 $7.3 \mathrm{~dB} \mathrm{HL}$ 이었으며, 기도-골도 차는 양측 모두 $1.3 \mathrm{~dB} \mathrm{HL}$ 로 대상자 모두 $20 \mathrm{~dB} \mathrm{HL}$ 이하의 정상 청력 기준을 충족하였 다. 실험에 참여하기 전 연구 대상자들은 연구의 목적과 방법에 대하여 자세한 설명을 듣고 이해한 후 참여 동의서에 서명을 하였다. 모든 연구에 대한 절차 및 내용은 한림대학교 생명윤리 위원회로부터 승인 받았다(\#HIRB-2016-083).

\section{이어폰 종류}

본 연구에서는 외이도 삽입 정도에 따라 이어커널(ear-canal; MS300BA, Phiaton, Seoul, Korea) (Figure 1A), 이어버드(earbud; MDR-E9LP/BC, Sony, Tokyo, Japan) (Figure 1B), 이어클 립(ear-clip; C150H, Cresyn, Seoul, Korea) (Figure 1C), 헤드폰 (headphone; C555H, Cresyn) (Figure 1D)을 사용하였다. 이어 폰 종류에 따라 외이도에 삽입되는 거리를 실측하기 위하여 연 구 대상자들의 이주(tragus)와 접하는 부분을 이어폰에 표시하 여 그 거리를 측정하고 평균값을 계산하였다. 예를 들어, 성인 의 평균 외이도 길이를 $2.5 \sim 3 \mathrm{~cm}$ 로 감안하여 계산하였을 때 (Alvord \& Farmer, 1997), 이어커널형의 삽입 정도는 $1.7 \mathrm{~cm}$, 이어버드는 $1.2 \mathrm{~cm}$ 였다. 이어클립과 헤드폰의 경우 삽입이 아닌 이주를 기준으로 외이도 외측에 위치하기 때문에 이주와 접하 는 부분을 기준으로 출력 위치와의 거리를 측정하였다. 이어클 립과 헤드폰 자체의 길이는 각각 $0.6 \mathrm{~cm}, 1.3 \mathrm{~cm}$ 였고, 평균 성인 의 외이도 길이인 $2.5 \mathrm{~cm}$ 를 더하여 이어클립 $3.1 \mathrm{~cm}$, 헤드폰 3.8 $\mathrm{cm}$ 로 계산되었다. 
Figure 1. Insertion depth-of four earphone types in the ear canal. A: Ear-canal, B: Ear-bud, C: Ear-clip, D: Headphone.

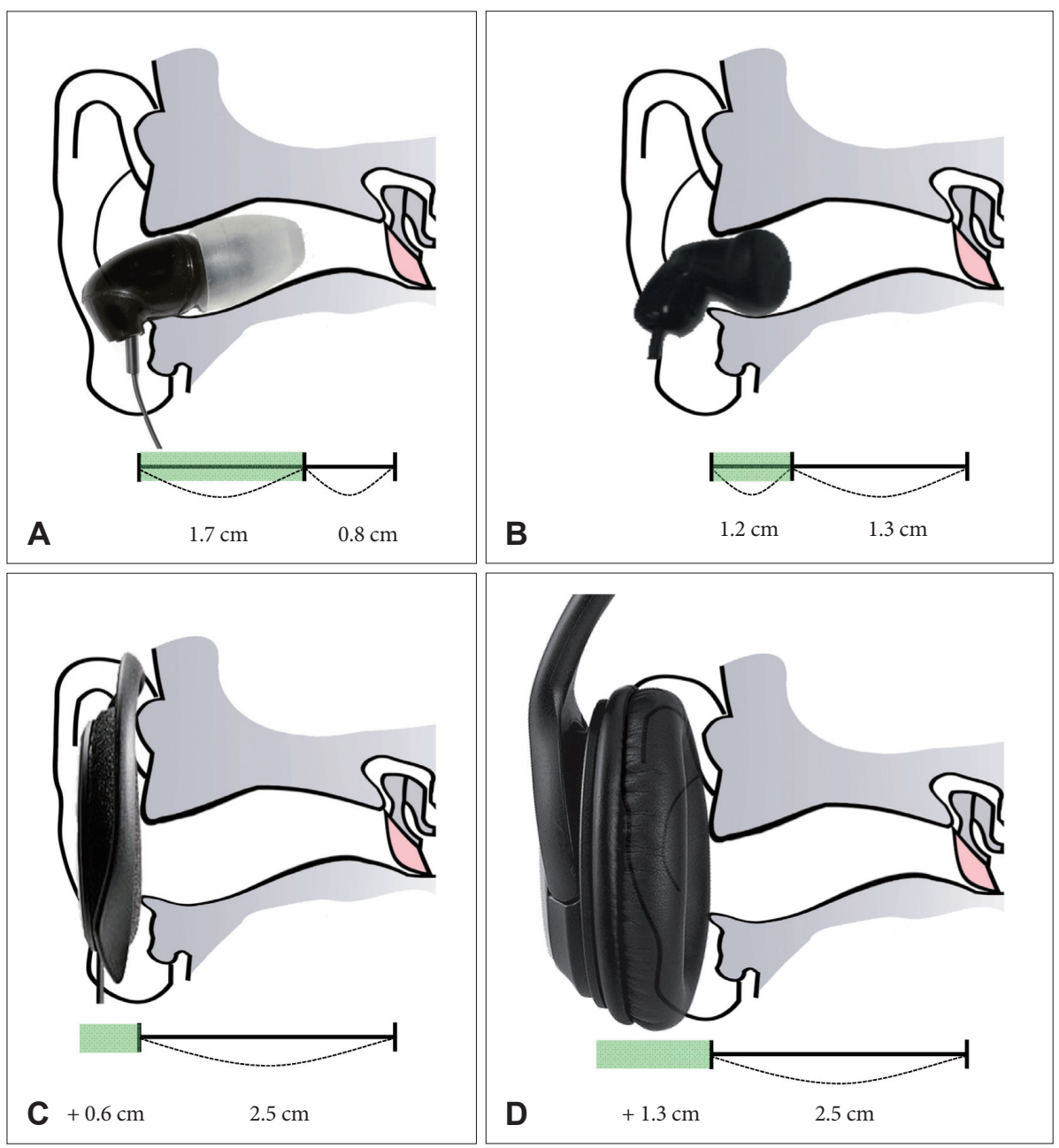

본 연구에서 사용한 이어폰들의 외이도 삽입 정도를 제외하 고 주파수, 감도, 인피던스 등 음향적인 특성에서의 동질성을 확인하기 위해 실이측정장비(Verifit 2, Audioscan, Dorchester, $\mathrm{ON}, \mathrm{Canada)}$ 를 통하여 주파수 성능 분석을 실시하였다. 이어커 널형은 $0.3 \mathrm{kHz}$ 부터 하강하고 $2 \mathrm{kHz}$ 부터는 완만한 곡선을 보 였다(Figure 2A). 이어버드는 $1 \mathrm{kHz}$ 부분에서 높은 이득을 보 였으며 그 이후로 하강하는 곡선을 보이다가 $6 \sim 8 \mathrm{kHz}$ 에서 다 시 상승세를 보였다(Figure 2B). 이어클립은 $0.3 \mathrm{kHz}$ 이후 하강 을 하다가 $1 \mathrm{kHz}$ 부분에서 높은 이득을 보였고 $2 \mathrm{kHz}$ 와 6 $\mathrm{kHz}$ 부분에서도 일정 부분 이득을 보였다(Figure $2 \mathrm{C}$ ). 헤드폰 의 경우, 앞선 이어클립과 비슷하게 특정 주파수 부분(예를 들 어, 1, 3, $6 \mathrm{kHz}$ )에서 이득을 보였다(Figure 2D). 세부적인 특징 들은 조금씩 상이했으나, 고주파수에 비해 저주파수 대역에서 의 큰 진폭을 갖는 패턴은 이어폰 간 매우 유사하였다.

\section{음악 선정}

본 연구에서는 클래식, 발라드, 댄스, 힙합의 총 4가지 장르를
적용하였고, 각 장르별 음악 선정을 위해 Mnet (www.mnet. com)에서 2016년 1 12월 기간 동안 가장 많이 누적 청취된 음 악 순위 1 위를 선택하였다. 클래식은 베토벤의 'Moon light', 발 라드는 한동근의 '이 소설의 끝을 다시 써보려 해', 댄스곡은 트 와이스의 'Cheer-up', 마지막으로 힙합은 지코의 'boys and girls' 를 선정하였다. 또한 음향 편집 프로그램(Cool Edit Pro, Ver. 2.1, Adobe System Co., San Jose, CA, USA)을 이용하여 각 노래의 1절만 추출하여 사용해, 선행논문들에서 반복되는 후렴구만 측정한 것과 달리 실질적인 선호청취음량을 측정하되 피검자가 오랜 검사 참여 시간에 따른 지루함으로 결과의 신뢰도가 낮아 지는 것을 최소화하였다.

\section{연구 절차}

방음실에서 스피커와 마주본 상태로 $1 \mathrm{~m}$ 거리의 의자에 앉아, 준비된 아이패드(I-pad, Apple, Cupertino, CA, USA)를 통하여 4가지의 이어폰 종류(이어커널, 이어버드, 이어클립, 헤드폰)와 3 가지 배경소음 수준[조용한 상황, 가정의 평균 생활소음인 40 


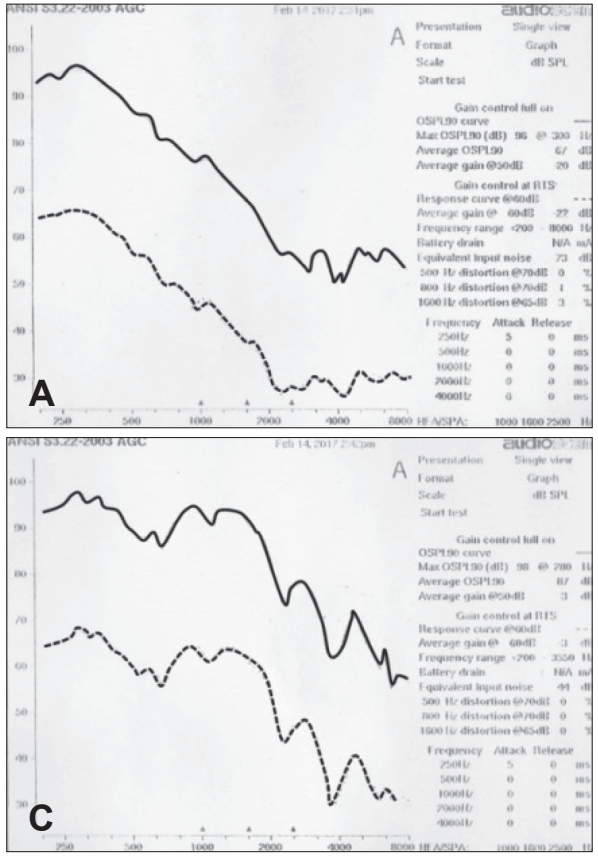

Figure 2. Amplitude-frequency analysis of the four earphone types using Verifit 2 (Audioscan). A: Ear-canal, B: Ear-bud, C: Ear-clip, D: Headphone.
$\mathrm{dBA}$ 의 다화자잡음(Shin et al., 2015), 혼잡한 거리소음인 70 $\mathrm{dBA}$ 의 다화자잡음(Park et al., 2009)]에서 4가지 음악 장르(클 래식, 발라드, 댄스, 힙합)를 각각 1곡씩 청취하였다. 모든 조건은 무작위(pseudo-randomized)로 진행되었으며, 각 조건에서 대상 자는 본인이 듣기 선호하는 청취 볼륨으로 음악을 청취하며, 언 제든지 음악의 볼륨을 자유롭게 조절할 수 있음을 설명하였다. 선호청취음량의 변화는 연구 대상자가 착용한 이어폰과 연결된 소음측정기(Sound Level Meter, Type 2250, Brüel \& Kjær, Nærum, Denmark)를 통하여 측정하였다. $70 \mathrm{dBA}$ 다화자잡음 에서의 음악 청취 시, 귀에 무리가 가지 않기 위해 연구 대상자의 요청이 있을 시 여러 번의 휴식을 취하면서 진행하였다.

더불어, 각 연구 참여자들의 수용소음레벨을 결정하기 위하여, 기존에 제작된 한국어 수용소음레벨 음원(Shin \& Lee, 2010) 중 남자 1 명의 목표 이야기와 남, 여 각각 4 명씩으로 구성된 총 8명의 다화자잡음을 사용하여 수용소음레벨을 측정하였다. 음 원은 방음실 내에서 CD플레이어(AH64-05043G, Samsung, Seoul, Korea)와 연결된 노트북(U45x, Hansung computer, Seoul, Korea)을 통해 청력검사기(GSI-61, Grason-Stadler, Eden prairie, MN, USA)에서 재생하여 제시된 목표 이야기를 듣고 대상자가 원하는 크기의 최고 쾌적 수준(most comfortable level, MCL)을 구하였다. 이때 연구 대상자는 오른손을 통 하여 현재의 소리 크기보다 소리가 커지길 원한다면 오른손 검 지를 위로 향하게 하였다. 반대로, 소리가 좀 더 작기를 원한다면 검지를 아래로 향하게 설명하였다. 그 다음 목표 이야기를 측정 된 최고 쾌적 수준에서 들려주면서 동시에 동측 스피커에서 다 화자잡음을 제시하여 연구 대상자 개개인이 최대로 수용 가능한 배경소음레벨(background noise level, BNL)을 측정하였다. 배경 소음레벨 측정 시, 검사 설명은 ‘이야기 소리가 잘 들리면서, 배경 소음은 시끄럽지만 참을 수 있는 소리 수준이 되면 손으로 “그 만”을 표시하세요로 통일하였다. 두 가지의 검사를 마친 뒤, 선행 연구와 동일한 방식으로 각 검사의 수치의 차이 $(\mathrm{MCL}-\mathrm{BNL}=$ $\mathrm{ANL}$ )로 수용소음레벨을 산출하였다(Shin \& Lee, 2010).

\section{자료 및 통계 분석}

아이패드(I-pad)와 연결된 이어폰을 통해 재생되는 노래의 음압 강도를 측정하기 위하여 소음측정기(Sound Level Meter, Type 2250)와 1/2인치 마이크로폰(Type 4192, Brüel \& Kjær) 을 사용하였다. 이어폰을 통해 나오는 음압 강도는 소음측정기를 인공 귀(Type 4153, Brüel \& Kjær)와 2-cc 커플러(Type 4946, Brüel \& Kjær)에 이어폰을 연결하여 사용하였다. 소음측정기 (Sound Level Meter, Type 2250)로 측정된 선호청취음량을 전 문 분석 프로그램인 Bz-5503 (Brüel \& Kjær)을 이용하여 등가 소음도(equivalent levels in A-weighted)로 분석하였다.

네 가지의 이어폰 종류와 세 가지의 소음 수준에 따른 네 가 지 음악 장르의 선호청취음량 수준을 표준화된 통계 프로그램 (SPSS, ver. 23.0, IBM Corp., Armonk, NY, USA)을 이용하여 삼원분산분석(three-way Analysis of Variance)을 실시하였다 $(p<0.05)$. 통계적 유의성을 확인한 후, Bonferroni 사후검정 (post-hoc comparison)을 사용하여 이어폰 삽입 정도, 배경소 음 정도, 음악 장르 간의 유의했던 부분을 확인하였다. 또한, 수 용소음레벨과 선호 음량 수준의 상관관계를 Pearson Correlation을 통하여 분석하였다. 


\section{RESULTS}

Figure 3은 3가지 외적 요인(exogenous factor)에 따라 선호 청취음량의 변화를 확인하였다. 모든 음악 장르에서 이어커널 형이 가장 낮은 음량을 나타냈고, 이어클립형이 가장 높은 음 량을 보여주었다. 배경소음의 정도가 증가할수록 모든 조건에 서 동일하게 선호청취음량이 증가하는 패턴을 보여주었다. 그 러나 이개를 전체적으로 감싸는 헤드폰의 경우, 이어버드와 동 일한 정도의 음량을 나타냈다.

\section{배경소음 수준에 따른 선호청취음량}

3 가지의 서로 다른 배경소음 정도에 따라, 조용한 상황이 $72.29 \mathrm{dBA}, 40 \mathrm{~dB}$ 다화자잡음에서 $76.95 \mathrm{dBA}, 70 \mathrm{~dB}$ 다화자 잡음에서 $87.02 \mathrm{dBA}$ 순으로 배경소음 정도가 증가함에 따라, 선호청취음량도 유의미하게 증가하였다 $[\mathrm{F}(1.471,55,896)=$ $210.741, p=0.000]$. 사후 분석 결과, 조용한 상황, $40 \mathrm{~dB}$ 다화
자잡음, $70 \mathrm{~dB}$ 다화자잡음 간 모두 유의미한 차이를 보여 $(p=$ $0.000)$, 배경소음 정도가 커질수록 선호청취음량은 커지는 현 상을 보였다.

\section{음악 장르에 따른 선호청취음량의 변화}

서로 다른 4 가지의 음악 장르별 선호청취음량을 분석하였다. 클래식이 $71.10 \mathrm{dBA}$ 로 가장 낮은 선호청취음량을 보였으며, 힙 합이 $80.47 \mathrm{dBA}$, 댄스가 $81.62 \mathrm{dBA}$ 로 점차 증가하였다. 발라드 는 $81.83 \mathrm{dBA}$ 로 음악 장르 중 가장 높은 선호청취음량을 나타 내었다. 각 장르별 선호청취음량을 비교 결과 $[\mathrm{F}(1.222,46.438)=$ $108.789, p=0.000]$ 통계적으로 유의미한 차이를 보였다. 사후 분석 결과, 클래식-발라드, 클래식-댄스, 클래식-힙합, 발라드힙합 $(p=0.000)$, 댄스-힙합 $(p=0.002)$ 에서는 통계적으로 유의 미한 차이를 보였으나, 발라드-댄스의 경우는 유의미하지 않았 다 $(p=1.000)$.

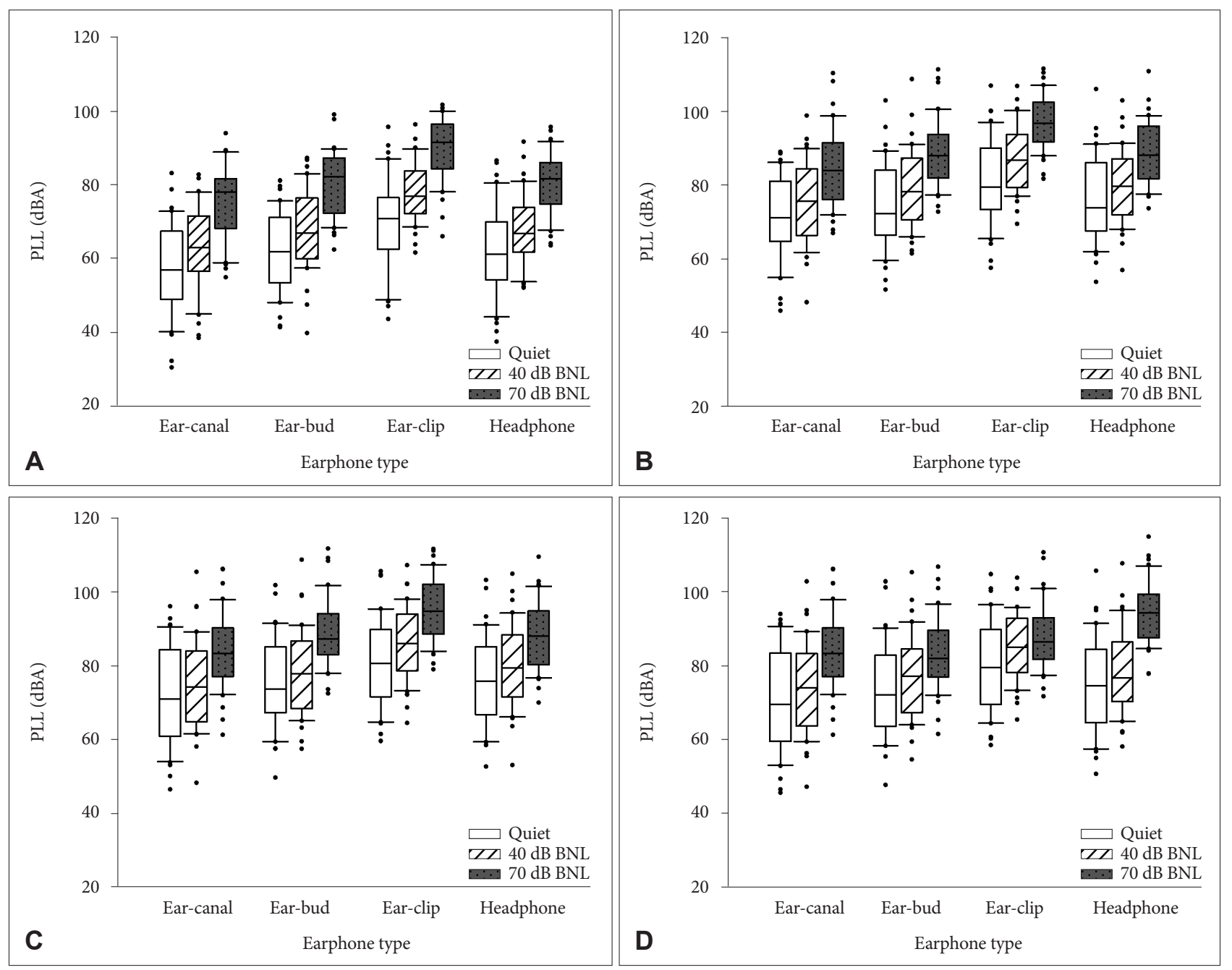

Figure 3. PLLs of four earphone types in the music genres. A: Classic. B: Ballad (or R\&B). C: Dance. D: Hip-hop. PLL: preferred listening level, BNL: background noise level. 


\section{이어폰 종류에 따른 선호청취음량의 변화}

삽입 정도가 서로 다른 4 가지 이어폰을 적용하여, 청취선호 음량을 분석하였다. 이어커널의 평균 선호청취음량은 73.86 $\mathrm{dBA}$, 이어버드는 $77.68 \mathrm{dBA}$, 이어클립은 $85.26 \mathrm{dBA}$, 헤드폰 은 $78.22 \mathrm{dBA}$ 이었다. 연구 대상자는 고막과의 거리가 가장 가 까운 이어커널을 사용할 때 가장 작은 선호청취음량을 보였으 며, 고막과의 거리가 가장 먼 이어클립 사용 시 가장 큰 선호청 취음량을 보였다. 즉, 외이도 내 이어폰 삽입 정도가 멀어질수록 유의미하게 선호청취음량이 높아졌다 $[\mathrm{F}(2.118,80.485)=$ $190.351, p=0.000]$. 사후 분석 결과, 이어커널-이어버드, 이어커 널-이어클립, 이어커널-헤드폰, 이어버드-이어클립, 이어클립-헤 드폰 모든 상황에서 통계적으로 유의미한 차이를 보였으나 $(p=$ $0.000)$, 이어버드-헤드폰 간은 유의미하지 않았다 $(p=1.000)$.

\section{수용소음레벨과 선호청취음량과의 상관성}

40명의 연구 대상자들에게 측정된 수용소음레벨의 평균은 $-0.28 \mathrm{~dB}$ 이었고, 표준편차는 \pm 3 이었다. 이를 바탕으로 배경소 음, 음악 장르, 이어폰 종류에 따라 각각 측정된 선호청취음량 과 수용소음레벨과의 상관관계를 분석하였다. Table 1 의 분석 결과를 보면, 클래식 음악의 경우를 제외하고는 발라드, 댄스,
힙합의 음악 장르에서 대부분의 이어폰 종류와 배경소음 정도 와 수용소음레벨 간 상관성을 보였다. 특히 $70 \mathrm{~dB}$ 의 다화자소 음에서, 댄스를 이어커널형으로 듣거나, 힙합을 이어커널 혹은 헤드폰으로 들을 때를 제외하고는 연구 대상자의 수용소음레 벨과 선호청취음량과는 유의미한 상관성을 나타냈다.

\section{DISCUSSIONS}

본 연구는 휴대용 음향기기의 사용 빈도가 가장 높은 20대 정 상 청력의 남·여 40명을 대상으로 음향기기의 선호청취음량에 영향을 미치는 요인들을 외적 요인(exogenous factors) 및 내적 요인(endogenous factors)으로 구분하여 확인하였다.

\section{외적 요인에 따른 선호청취음량}

이어폰의 종류에 따라 선호청취음량이 변화되었다. 구체적으 로, 이어폰의 삽입 정도에 따른 선호청취음량을 분석한 결과, 삽입 정도가 가장 깊은(고막과의 거리가 가장 가까운) 이어커널 이 모든 상황에서 가장 낮은 선호청취음량을 보였으며, 삽입 정 도가 얕아질수록(고막으로부터 멀어질수록) 더 큰 선호청취음 량을 보였다. Kim et al.(2011)에서 이어폰의 고무마개가 외이도

Table 1. Pearson correlation coefficient between ANL with 8-talker masker and preferred listening levels

\begin{tabular}{|c|c|c|c|c|c|c|c|}
\hline \multicolumn{4}{|c|}{ ANLs } & \multicolumn{4}{|c|}{ ANLs } \\
\hline Classic & Ear-canal & Quiet & -0.25 & Ballad & Ear-canal & Quiet & $-0.33^{*}$ \\
\hline & & $40 \mathrm{~dB}$ & -0.21 & & & $40 \mathrm{~dB}$ & $-0.33^{*}$ \\
\hline & & $70 \mathrm{~dB}$ & -0.11 & & & $70 \mathrm{~dB}$ & -0.28 \\
\hline & Ear-bud & Quiet & $-0.40^{*}$ & & Ear-bud & Quiet & $-0.34^{*}$ \\
\hline & & $40 \mathrm{~dB}$ & $-0.31^{*}$ & & & $40 \mathrm{~dB}$ & $-0.43^{* *}$ \\
\hline & & $70 \mathrm{~dB}$ & -0.14 & & & $70 \mathrm{~dB}$ & $-0.35^{*}$ \\
\hline & Ear-clip & Quiet & -0.14 & & Ear-clip & Quiet & -0.23 \\
\hline & & $40 \mathrm{~dB}$ & -0.15 & & & $40 \mathrm{~dB}$ & -0.30 \\
\hline & & $70 \mathrm{~dB}$ & -0.02 & & & $70 \mathrm{~dB}$ & $-0.41^{* *}$ \\
\hline & Headphone & Quiet & -0.29 & & Headphone & Quiet & $-0.34^{*}$ \\
\hline & & $40 \mathrm{~dB}$ & -0.20 & & & $40 \mathrm{~dB}$ & -0.29 \\
\hline & & $70 \mathrm{~dB}$ & -0.17 & & & $70 \mathrm{~dB}$ & $-0.39^{*}$ \\
\hline \multirow[t]{12}{*}{ Dance } & Ear-canal & Quiet & $-0.39^{*}$ & Hip-hop & Ear-canal & Quiet & $-0.37^{*}$ \\
\hline & & $40 \mathrm{~dB}$ & $-0.38^{*}$ & & & $40 \mathrm{~dB}$ & $-0.35^{*}$ \\
\hline & & $70 \mathrm{~dB}$ & -0.28 & & & $70 \mathrm{~dB}$ & -0.29 \\
\hline & Ear-bud & Quiet & $-0.35^{*}$ & & Ear-bud & Quiet & $-0.38^{*}$ \\
\hline & & $40 \mathrm{~dB}$ & $-0.46^{* *}$ & & & $40 \mathrm{~dB}$ & $-0.46^{* *}$ \\
\hline & & $70 \mathrm{~dB}$ & $-0.37^{*}$ & & & $70 \mathrm{~dB}$ & $-0.36^{*}$ \\
\hline & Ear-clip & Quiet & $-0.34^{*}$ & & Ear-clip & Quiet & $-0.34^{*}$ \\
\hline & & $40 \mathrm{~dB}$ & $-0.39^{*}$ & & & $40 \mathrm{~dB}$ & $-0.40^{*}$ \\
\hline & & $70 \mathrm{~dB}$ & $-0.41^{* *}$ & & & $70 \mathrm{~dB}$ & $-0.37^{*}$ \\
\hline & Headphone & Quiet & $-0.41^{* *}$ & & Headphone & Quiet & $-0.43^{* *}$ \\
\hline & & $40 \mathrm{~dB}$ & $-0.36^{*}$ & & & $40 \mathrm{~dB}$ & $-0.40^{*}$ \\
\hline & & $70 \mathrm{~dB}$ & $-0.35^{*}$ & & & $70 \mathrm{~dB}$ & -0.28 \\
\hline
\end{tabular}

${ }^{*} p<0.05,{ }^{* *} p<0.01$. ANL: acceptable noise level 
를 완전히 막아 외부 소음의 유입을 차단한다는 주장이 본 연 구의 결과인 삽입 정도가 깊어질수록 필요 음량이 줄어든다는 것을 뒷받침하고 있다. 또한 Filgor \& $\operatorname{Cox}(2004)$ 의 연구를 살펴 보면, 외이도만 막는 이어클립형은 귀 전체를 감싸는 헤드폰에 비해 출력이 약 7 9 dB 높아지기 때문에 본 연구 결과에서처럼 이어커널-이어버드-이어클립은 순차적으로 음량이 높아지다가 헤드폰에서는 더 낮은 선호청취음량을 나타낸다고 추정된다.

또한 배경소음이 더해지면, $40 \mathrm{~dB}$ 다화자잡음 상황에서 이 어커널은 약 $72 \mathrm{dBA}$, 이어버드 약 $75 \mathrm{dBA}$, 이어클립 약 84 $\mathrm{dBA}$, 헤드폰 $76 \mathrm{dBA}$ 로 이어폰 삽입 정도가 깊어질수록 더 작 은 선호청취음량으로 측정되었고, 헤드폰은 조용한 상황과 동 일하게 이어버드와 비슷한 수준으로 측정되었다. 조용한 상황에 비해, 선호청취음량이 이어커널은 $8 \mathrm{dBA}$, 이어버드는 $4 \mathrm{dBA}$, 이어클립은 $6 \mathrm{dBA}$, 헤드폰은 $4 \mathrm{dBA}$ 정도 높아졌다. 예상한 대 로, 배경소음이 커지면서 선호청취음량이 증가한 것은 연구 대 상자가 일정 정도 선호하는 신호대잡음비가 있기 때문으로 추 정된다(Kim et al., 2011). 즉, 다화자잡음은 여러 사람의 육성 이기 때문에 음악을 명료하게 들리지 않게 한다. 따라서 노래 가사와 노랫소리를 명료하게 듣기 위해서는 신호(선호청취음 량)를 더 높인 것이라고 추정된다(Nabelek et al., 2004).

한편, $70 \mathrm{~dB}$ 다화자잡음 상황에서도 이어커널은 약 $82 \mathrm{dBA}$ 로 가장 작은 선호청취음량을 나타내었으며, 이어버드는 약 86 $\mathrm{dBA}$, 이어클립 약 $89 \mathrm{dBA}$, 헤드폰은 약 $88 \mathrm{dBA}$ 로 측정되었 다. 앞선 조용한 환경, $40 \mathrm{~dB}$ 다화자잡음 상황과 동일하게 외이 도 삽입 정도가 깊어질수록 더 작은 선호청취음량을 나타내었 으며, $70 \mathrm{~dB}$ 다화자잡음 상황에서는 이어폰 간의 차이는 줄어 들었다. 배경소음의 양이 증가할수록 더 높은 선호청취음량(이 득)을 선택하고, 음의 포화(saturation)가 일어나 이어폰 간의 차이가 줄어들었다고 해석할 수 있다(Rigrod, 1965). Kim et al. (2011)의 연구에서도 $70 \mathrm{~dB}$ 대화소음에서 이어커널은 $67.9 \mathrm{dBA}$, 이어버드는 $72.5 \mathrm{dBA}$, 이어클립은 $77.5 \mathrm{dBA}$ 로 측정되었다. 이 는 본 연구의 결과와 동일하게 삽입 정도에 따라 선호청취음량 이 줄어들었다. 그러나 본 연구보다 더 작은 선호청취음량을 나 타낸 이유로는 Kim et al.(2011)에 사용된 $70 \mathrm{~dB}$ 대화소음은 기차가 들어오지 않는 시점에 약 100여 명의 사람이 무작위로 서로 대화하는 소음을 녹음한 것을 연구 시 측정되었던 크기 로 재생시킨 반면, 본 연구는 남·여 4명씩(총 8명)이 음성분석 프로그램(Computerized Speech Lab, Hoya Co., Tokyo, Japan) 을 이용하여 녹음을 해 Cool edit 프로그램(Ver. 2.1)을 사용하 여 정격 출력(root mean square) 작업을 진행하였기 때문에 선 호청취음량에 차이가 나타났을 것으로 추정된다(Shin \& Lee, 2010). 한편, Henry \& Foots(2012) 연구에서는 $80 \mathrm{dBA}$ 백색잡 음 상황에서 이어커널은 $73.8 \mathrm{dBA}$, 이어버드 $81.9 \mathrm{dBA}$ 로 이어
커널이 더 작은 선호청취음량을 나타냈다. 배경소음 상황이 달 라 직접적인 비교는 어렵지만, 삽입 정도가 더 깊은 이어커널이 이어버드보다 더 작은 선호청취음량을 보이는 것은 본 연구와 유사했다. Hodgetts et al.(2007)의 연구에서 $70 \mathrm{~dB}$ 다화자잡음 에서 이어버드는 $86.7 \mathrm{dBA}$, 헤드폰은 $82.9 \mathrm{dBA}$ 로 조용한 상황 과 동일하게 헤드폰의 선호청취음량이 더 낮게 측정되었다. 본 연구에서 이어버드 $86 \mathrm{dBA}$, 헤드폰 $88 \mathrm{dBA}$ 의 결과와 이어버 드 값은 동일하지만 헤드폰의 경우 약 $5 \mathrm{~dB}$ 의 차이가 난다. 앞 서 언급한 것과 같이 본 연구와의 연구 시기 차이로 인한 사용 이어폰의 스펙의 차이라고 추정된다.

음악 장르에 따라 선호청취음량이 유의미하게 상이하였다. 조용한 상황에서 클래식의 선호청취음량은 약 $63 \mathrm{dBA}$ 로 가장 낮았으며, 힙합은 약 $75 \mathrm{dBA}$, 댄스 약 $76 \mathrm{dBA}$, 발라드 약 76 $\mathrm{dBA}$ 의 선호청취음량을 보였다. Airo et al.(1996) 연구에서는 클래식이 $67.7 \mathrm{dBA}$, 팝송은 $63.2 \mathrm{dBA}$, 메탈은 $71.8 \mathrm{dBA}$, 로큰 롤은 $73.2 \mathrm{dBA}$ 의 선호청취음량을 나타내었다. 연구가 진행되었 던 나라의 사용 언어와 장르가 달라서 직접적인 비교는 어렵지 만, 추후 연구에서 다양한 특색을 가진 노래를 장르로 나누어 진행하게 된다면, 선호청취음량의 장르별 대표성을 나타낼 수 있을 것이다. 조용한 상황에서 음악 간의 차이를 보이는 이유는 음악 자체가 지닌 음악 특성, 음악을 통해 느끼는 개인적인 감 성과 선호도에 따른 차이 때문이다(Shim et al., 2018). $40 \mathrm{~dB}$ 다화자잡음에서 클래식이 약 $69 \mathrm{dBA}$ 로 가장 낮은 선호청취음 량을 보였으며, 힙합이 약 $79 \mathrm{dBA}$, 댄스가 약 $80 \mathrm{dBA}$, 발라드 가 약 $80 \mathrm{dBA}$ 의 선호청취음량을 보였으며, $70 \mathrm{~dB}$ 다화자잡음 에도 클래식이 약 $81 \mathrm{dBA}$ 로 가장 낮은 청취 음량을 나타내었 고, 힙합이 약 $88 \mathrm{dBA}$, 댄스가 약 $89 \mathrm{dBA}$, 발라드가 약 90 $\mathrm{dBA}$ 의 선호청취음량을 보였다. 배경소음이 커졌을 때 음악 간 의 차이가 줄어드는 이유로는 대부분의 현대음악은 구조, 길이 및 역동 범위가 매우 유사하기 때문으로 분석된다(Kähäri et al., 2011).

\section{내적 요인에 따른 선호청취음량}

외이도의 삽입 정도에 따른 선호청취음량과 수용소음레벨에 서 가장 두드러진 반비례적 상관성을 보이는 이어폰은 이어버 드였다. 즉, 이어버드는 12 가지(3가지 배경소음 $\times 4$ 가지 음악 장르)에서 가장 많은 11 가지의 상황에서 유의미한 상관성을 보였 고, 이어클립이 7가지 상황, 헤드폰이 7가지 상황, 이어커널이 6가 지 상황에서 유의미한 상관성을 보였다. 이어버드가 수용소음 레벨과 가장 두드러진 상관성을 보인 이유는 두 가지로 분석해 볼 수 있겠다. 첫째, 이어버드 이어폰의 경우 실이측정 결과에 서 다른 이어폰 유형들보다 중저음대역에서는 높고 고음역에서 는 낮은 특징을 보였다. 둘째, 사용된 4가지의 이어폰 유형들 
중 가장 오래되고 저가형 모델이었다. 즉, 오래되고 저가형 모델 들은 주로 선형의 형태로 제작이 되었기에 이어버드가 이러한 선형의 모습을 특색 있게 나타냈다고 사료된다.

기존 연구들을 살펴보면, 아직 수용소음레벨과 소음 속 어음 인지검사 간 유의미한 관련성이 밝혀지지는 않았다(Nabelek et al., 2004). 사실상 소음 속 어음인지검사는 소음 속에 언어 프 로세스가 있는 문장을 이해한 뒤 따라서 말하거나 문제에 답 을 구하는 방식이다. 반면, 수용소음레벨은 이야기의 단어를 듣는 동안 언어 프로세스가 없는 배경소음을 허용하려는 과정 에서 불편하지만 소리가 잘 들리는지 측정하기 때문에 그 상관 성을 밝히기가 쉽지 않다(Nabelek et al., 2004). 본 연구 결과 에서는 언어 프로세스가 있는 댄스가 12 가지 상황 중 11 가지 상황에서 수용소음레벨과의 유의미한 상관성을 가장 많이 보 였다. 오히려, 언어 프로세스가 없는 클래식에서 12 가지 상황 중 2 가지 상황에서만 수용소음레벨과의 유의미한 상관성을 보 였다. 해당 댄스의 경우 반복되는 코러스 부분이 다른 장르 노 래에 비해 확연히 많았다. 본 연구에서 새롭게 시도한 음악 청 취 시 요구되는 선호 음량과 수용소음레벨은 어느 정도의 상관 성을 보여주었다. 따라서 본 연구의 의미 있는 결과는 추후 보 다 심도 있는 실험 설계의 후속 연구를 통하여 둘 간의 명확한 상관성을 밝히는 데 도움이 될 것으로 생각된다.

본 연구는 다음과 같은 제한점을 가지고 있었다. 첫째, 개인 음향기기의 사용 빈도에 상관없이 20 대의 정상 청력을 지닌 연 구 대상자의 자발적인 참여로 실험이 진행되었다. Kähäri et al. (2011)의 연구에서는 개인 음향기기를 통하여 자주 음악을 청 취하는 연구 대상자는 자주 청취하지 않는 대상자보다 높은 음 량을 선호할 가능성이 약 4배 더 높았다고 보고하였다. 따라서 추후 연구에서는 청취 습관을 설문 조사를 통하여 개인의 성향 차로 인해 영향을 주는 요인들에 대해 좀 더 자세히 분석할 필 요가 있다. 즉, 자주 음악을 청취하는 그룹(예를 들어, 노래를 오 래 듣는 그룹)과 자주 음악을 청취하지 않는 그룹(노래를 오래 듣지 않는 그룹)으로 조건화된 실험을 진행한다면, 본 연구의 결과와는 다른 선호청취음량을 나타낼 것으로 기대한다. 둘째, 이어클립을 제외한 헤드폰, 이어커널, 이어버드는 각각의 차이 는 존재하나 모두 외이도를 막아 압력이 발생한다. 착용 시 발 생할 수 있는 압력의 정도를 측정하여 이어폰 삽입 정도에 따 라 추가적으로 발생되는 이득(낮은 선호청취음량)을 고려해야 하겠다. 이를 위해 40명으로 진행된 본 연구의 참여 대상자 수를 충분히 늘려서 일반화된 결과를 도출해야 할 필요성이 있다.

중심 단어 : 선호청취음량·이어폰 종류·이어폰의 삽입 정도· 음악 장르·수용소음레벨.

\section{Ethical Statement}

All participants signed an informed consent form before beginning the experiment. The procedures were approved by the Institutional Review Board of Hallym University (\#HIRB-2015-027).

\section{Acknowledgments}

The authors thank the participants' time and contribution for the experiment.

\section{Declaration of Conflicting Interests}

There are no conflict interests.

\section{Funding}

This research was completed while being supported by National Research Foundation of Korea (NRF-2017R1A1A1A05001299).

\section{REFERENCES}

Airo, E., Pekkarinen, J., \& Olkinuora, P. (1996). Listening to music with earphones: An assessment of noise exposure. Acta Acustica united with Acustica, 82(6), 885-894.

Alvord, L. S. \& Farmer, B. L. (1997). Anatomy and orientation of the human external ear. Journal of the American Academy of Audiology, 8(6), 383390.

Fligor, B. J. \& Cox, L. C. (2004). Output levels of commercially available portable compact disc players and the potential risk to hearing. Ear and Hearing, 25(6), 513-527.

Franklin, C. A. Jr., Thelin, J. W., Nabelek, A. K., \& Burchfield, S. B. (2006), The effect of speech presentation level on acceptance of background noise in listeners with normal hearing. Journal of the American Academy of Audiology, 17(2), 141-146.

Henry, P. \& Foots, A. (2012). Comparison of user volume control settings for portable music players with three earphone configurations in quiet and noisy environments. Journal of the American Academy of Audiology, 23(3), 182-191.

Hodgetts, W. E., Rieger, J. M., \& Szarko, R. A. (2007). The effects of listening environment and earphone style on preferred listening levels of normal hearing adults using an MP3 player. Ear and Hearing, 28(3), 290-297.

Kähäri, K. R., Aslund, T., \& Olsson, J. (2011). Preferred sound levels of portable music players and listening habits among adults: A field study. Noise and Health, 13(50), 9-15.

Kim, K. W., Jung. J. Y., \& Seo, M. H. (2011). Effects of earphone style and noise environment on listening levels when using portable music players in the laboratory. Communication Sciences and Disorders, 16(3), 408-415.

Kumar, A., Mathew, K., Alexander, S. A., \& Kiran, C. (2009). Output sound pressure levels of personal music systems and their effect on hearing. Noise and Health, 11(44), 132-140.

Lee, J., Gu, J. H., Park, H. G., \& Lee, W. S. (2013). The survey for the maximum noise level of portable audio equipment and its assessment. Transactions of the Korean Society for Noise and Vibration Engineering, 23(1), 3-8.

Minges, M. (2012). Key trends in the development of the mobile sector. In The World Bank. 2012 Information and Communications for Development: Maximizing Mobile (pp.115-134). Washington, DC: The World Bank.

Nabelek, A. K., Tampas, J. W., \& Burchfield, S. B. (2004). Comparison of speech perception in background noise with acceptance of background noise in aided and unaided conditions. Journal of Speech, Language, and Hearing Research, 47(5), 1001-1011.

Park, H., Baek, H., \& Kim, S. (2009). Fundamental study on the physical evaluation of single or combined noises in the combined noise environment. Journal of the Architectural Institute of Korea Planning and Design, 25(3), 263-270. 
Rigrod, W. W. (1965). Saturation effects in high-gain lasers. Journal of Applied Physics, 36(8), 2487-2490.

Shim, H., Lee, S., Koo, M., \& Kim, J. (2018). Analysis of output levels of an MP3 player: Effects of earphone type, music genre, and listening duration. Journal of Audiology and Otology, 22(3), 140-147.

Shin, J. B. \& Lee, J. H. (2010). Effects of the target talker gender and the number of competing talkers on acceptable noise level (ANL) of Korean normal-hearing adults. Audiology, 6(2), 146-152.

Shin, J., Song, H., \& Shin, Y. (2015). Analysis on the characteristic of living noise residential buildings. Journal of the Korea Institute of Building
Construction, 15(1), 123-131.

Sliwinska-Kowalska, M. \& Davis, A. (2012). Noise-induced hearing loss. Noise and Health, 14(61), 274-280.

Vogel, I., van de Looij-Jansen, P. M., Mieloo, C. L., Burdorf, A., \& de Waart, F. (2012). Risky music-listening behaviors and associated health-risk behaviors. Pediatrics, 129(6), 1097-1103.

Yu, J., Lee, D., \& Han, W. (2016). Preferred listening levels of mobile phone programs when considering subway interior noise. Noise and Health, 18(80), 36-41. 